\title{
POTASSIUM FERTILIZATION, COMPOST AND BIO-FERTILIZER FOR IMPROVING POTATO PRODUCTIVITY, ITS QUALITY AND PROFITABILITY IN SANDY SOIL
}

\author{
R. A. El-Dissoky, Dalia A. Sayed and Amal H. EL-Guibali \\ Soils, Water and Environment Res. Inst., Agric. Res. Center, Giza, Egypt. \\ R.eldissoky@yahoo.com
}

Received: May 23, 2016

Accepted: Jun. 8, 2016

\begin{abstract}
Nutrient management become more important to be discussed to obtain optimum yield with maximum profitability, So, two field experiments were conducted in spilt plot design at El-Sharawy village in EL-Bostan area - Noubaria Region, Elbehera governorate (Latitude $30^{\circ} 43^{\prime} 22.01^{\prime \prime} \mathrm{N}$, Longitude $30^{\circ} 16^{\prime} 44.50^{\prime \prime} \mathrm{E}$ ) during the winter growing seasons of 2014 and 2015 on potato (c.v. spunta), to evaluate the effect of organic manure at two rates (10 and $20 \mathrm{~m}^{3}$ compost $\mathrm{fed}^{-1}$ ) with or without seed potato inoculation with potassium release bacteria (KRB) "Bacillus circulans" (Org ${ }_{1}, \mathrm{Org}_{1}+\mathrm{Bio}, \mathrm{Org}_{2}$ and $\mathrm{Org}_{2}+$ Bio ), four $\mathrm{K}$ treatments ( $\mathrm{K} 1: 96 \mathrm{~kg} \mathrm{~K}_{2} \mathrm{O} \mathrm{fed}^{-1}$ as $\mathrm{K}$-sulfate (SOP), $\mathrm{K} 2: 48 \mathrm{~kg} \mathrm{~K}_{2} \mathrm{O} \mathrm{fed}^{-1}$ as SOP+ $1 \% \mathrm{~K}_{2} \mathrm{O}$ foliar as SOP, K3: $48 \mathrm{~kg} \mathrm{~K}_{2} \mathrm{O} \mathrm{fed}{ }^{-1}$ as feldspar (FDS) $+1 \% \mathrm{~K}_{2} \mathrm{O}$ foliar and $\mathrm{K} 4: 24 \mathrm{~kg} \mathrm{~K}_{2} \mathrm{O}$ fed ${ }^{1}$ as FDS $+1 \% \mathrm{~K}_{2} \mathrm{O}$ foliar) and their interactions on potato yield and quality. Results reveal that addition of different $K$-treatments as SOP or FDS with foliar spray of $1 \% \mathrm{~K}_{2} \mathrm{O}$ significantly affected shoot fresh and dry weights, tuber yield and its quality parameters (specific gravity, starch and carbohydrate \%) and NPK-uptake in favor of SOP. Also, the values of plant growth parameters, tuber yield, tuber quality parameters and NPK-uptake were increased with increasing compost rate from 10 to 20 $\mathrm{m}^{3} \mathrm{fed}^{-1}$ along with KRB inoculation. Interaction between $\mathrm{Org}_{2}+$ Bio and $\mathrm{K} 2$ produced the highest values of tuber yield (16.697 $t$ fed $\left.^{1}\right)$ and NPK-uptake, whereas, higher values of tuber quality parameters were recorded under interactions of $\left(\mathrm{Org}_{1}+\mathrm{Bio}^{*} \mathrm{~K} 2\right.$ or K3) and $\left(\mathrm{Org}_{2}+\mathrm{Bio}^{*} \mathrm{~K} 2\right.$ or K3). For economic evaluation, results showed that $K 2$ and $K 3$ treatments along with $10 \mathrm{~m}^{3}$ compost $\mathrm{fed}^{1}+$ Bio were superior for net return (NR) and investment factor (IF), since the highest values of NR and IF were 11247 L.E fed ${ }^{1}$ and 1.93 with interaction $\mathrm{Org}_{1}+\mathrm{Bio}^{*} \mathrm{~K} 3$.
\end{abstract}

Key words: potassium, feldspar, compost, K-releases bacteria, sandy soil, potato yield and its quality, NPK-uptake and economic evaluation.

\section{INTRODUCTION}

Potato (Solanum tuberosum L.) is one of the most important vegetable crops in Egypt, that requires high amounts of potassium fertilizer for optimum growth, production and tuber quality (Al-Moshileh and Errebi 2004). Potassium is one of essential nutrients for plant that plays a vital role in photosynthesis, carbohydrate transport, protein formation, control of ionic balance, regulation of plant stomata and water use activation of plant enzyme and many other processes (Munson et al., 1985).
For economic and environmental reasons, nutrients management becomes more important to be discussed to obtain optimum yield with maximum profitability, especially for potassium fertilization. In this frame, change of the potato fertilization by potassium from traditional system (application of all K-requirements as Ksulfate fertilizer) to an integrated one consists of soil and foliar potassium applied from mineral fertilizers and natural sources such as feldspar and application of organic fertilizers with inoculation by bacteria 
dissolving potassium (Bacillus circulans) may be needed.

In this concern, El-Sawy et al., (2000) found that tuber yield, dry shoot weight, chemical composition of potato and specific gravity of tubers significantly increased with increasing K-foliar concentration (0, 1, 2 and $3 \% \mathrm{~K}_{2} \mathrm{O}$ as $\mathrm{K}_{2} \mathrm{SO}_{4}$ ), while tuber yield was significantly increased by increasing soil application of K-rate up to $48 \mathrm{~kg} \mathrm{~K}_{2} \mathrm{O}$ fed ${ }^{-1}$. Also, Gommaa (2007) showed that foliar K application at four concentrations $0,0.5,1.0$ and $1.5 \% \quad \mathrm{~K}_{2} \mathrm{O} \quad\left(\right.$ as $\quad \mathrm{K}_{2} \mathrm{SO}_{4}$ ) significantly increased potato tuber yield, and the highest tuber yield was at $1 \% \mathrm{~K}_{2} \mathrm{O}$. Dkhil et al., (2011) indicated that foliar of $2 \mathrm{~g} \mathrm{KNO}_{3} / \mathrm{L}$ was effective in increasing average tuber diameter, mean tuber weight of potato that grown on loamy-sandy soil. In another study, Singh and Lal (2012) showed that increasing $\mathrm{K}$ levels application up to $150 \mathrm{~kg}$ $\mathrm{K}_{2} \mathrm{O} \mathrm{ha}{ }^{-1}\left(63 \mathrm{~kg} \mathrm{fed}^{-1}\right)$ increased tuber yield, tuber size and $\mathrm{N}$ and $\mathrm{K}$ uptake by potato, which recorded maximum yield $\left(39.83 \mathrm{t} \mathrm{ha}^{-1}\right.$ $=16.7 \mathrm{t} \mathrm{fed}^{-1}$ ) on sandy loam soil.

In Egypt, there is a great need to optimize the use of the natural resources of nutrients to continue the development and sustainability of agriculture and reduce the cost of production and increase the net return. In this frame, Labib et al., (2012) showed that addition of $\mathrm{K}$ recommended for potato as $50 \%$ K-sulfate $+50 \%$ K-feldspar resulted in the highest content of starch, mono-sucrose and protein of potatoes, total yield and weight of vegetative plants as well as tubers comparing with using K-sulfate only at field study on sandy soil. Also, Shehata et al., (2014) found that application of $11.8 \mathrm{t}$ compost/fed+ $77 \mathrm{~kg}$ rock phosphate $+252 \mathrm{~kg}$ feldspar+ inoculation with mixture bacteria dissolving $\mathrm{P}$ and $\mathrm{K}(B$. megaterium and $B$. circulans) had the highest potato tubers weight per plant, total yield, NPK concentrations at tubers, dry matter and carbohydrate \% of potato tubers on sandy soil.

Regarding the use of organic fertilizers, Makaraviciute (2003) found that farmyard manure application increased dry matter and starch content in the tuber, where potato tuber yield increased by $20 \%$. Also, ElSayed et al., (2014) showed that treatment received $50 \%$ mineral fertilizers $+23.8 \mathrm{t}$. ha ${ }^{1}$ compost $\left(10 \mathrm{t}^{\mathrm{t}} \mathrm{fed}^{-1}\right)$ with bio-fertilizer had the highest weight of marketable tubers/plant on field study on sandy soil. Also, they indicated that organic production of potato using $23.8 \mathrm{t}$. ha ${ }^{-1}$ compost+ biofertilizer+ rock phosphate+ feldspar could be an alternative to conventional production without significant reduction in yield and quality on sandy soil under sprinkler irrigation.

So, the present study aims to increase the return of applied potassium, through the methods of K-fertilization (soil and foliar), sources of $\mathrm{K}$ (K-sulfate and feldspar) and compost application with inoculation by $\mathrm{K}$ release bacteria (Bacillus circulans) to obtain the optimum yield of potato with high quality and maximum economic return under sandy soil conditions.

\section{MATERIALS AND METHODS}

Two field experiments were conducted during the winter growing seasons 2014 and 2015 at El-Sharawy village in EL-Bostan area - Noubaria Region, Elbeheira governorate (Latitude $30^{\circ} 43^{\prime} 22.01 " \mathrm{~N}$, Longitude $30^{\circ} 16^{\prime} 44.50^{\prime \prime} \mathrm{E}$ ) to evaluate the effect of organic manure (compost) with or without inoculation by potassium release bacteria (bio-fertilizer), $\mathrm{K}$ fertilization and their interactions on potato yield (Solanum tuberosum, L. - c.v. Spunta), its quality and economic return under the conditions of sandy soil. Samples of the experimental soil and compost were analyzed before planting according to Hesse (1971) as shown in Tables 1 and 2. 
Table 1: Physical and chemical properties of the experimental soil before planting (mean of two seasons).

\begin{tabular}{|c|c|c|c|c|c|c|c|c|c|c|c|}
\hline \multirow{2}{*}{ Properties } & \multicolumn{6}{|c|}{ Particles size distribution } & \multirow{2}{*}{\multicolumn{2}{|c|}{$\underset{\%}{\mathrm{OM}}$}} & \multirow{2}{*}{$\underset{\%}{\mathrm{CaCO}_{3}}$} & \multirow[b]{2}{*}{$\mathrm{pH}$} & \multirow{2}{*}{$\begin{array}{l}E C \\
\mathrm{dSm}^{-1}\end{array}$} \\
\hline & $\begin{array}{c}\text { Sand } \\
\%\end{array}$ & \multicolumn{2}{|c|}{$\begin{array}{l}\text { Silt } \\
\%\end{array}$} & $\begin{array}{c}\text { Clay } \\
\%\end{array}$ & \multicolumn{2}{|c|}{ Texture class } & & & & & \\
\hline Values & 91.5 & & 5.4 & 3.1 & & Sandy & 0.1 & & & 8.1 & 0.41 \\
\hline \multirow{3}{*}{ Properties } & \multicolumn{8}{|c|}{$\begin{array}{l}\text { Cations and anions in the soil paste extract, } \\
\qquad\left(\text { meq } 100 \mathrm{~g}^{-1}\right)\end{array}$} & \multicolumn{3}{|c|}{$\begin{array}{l}\text { Available NPK } \\
\left(\mathrm{mg} \mathrm{kg}^{-1}\right)\end{array}$} \\
\hline & \multicolumn{4}{|c|}{ Cations } & \multicolumn{4}{|c|}{ Anions } & \multirow{2}{*}{$\mathrm{N}$} & \multirow{2}{*}{$\mathrm{P}$} & \multirow[b]{2}{*}{ K } \\
\hline & $\mathrm{Ca}^{++}$ & $\mathrm{Mg}^{++}$ & $\mathrm{Na}^{+}$ & $\mathrm{K}^{+}$ & $\mathrm{CO}_{3}^{--}$ & $\mathrm{HCO}_{3}^{-}$ & $\mathrm{Cl}^{-}$ & $\mathrm{SO}_{4}^{--}$ & & & \\
\hline Values & 1.61 & 1.28 & 1.02 & 0.18 & -- & 1.53 & 1.92 & 0.64 & 13 & 6 & 80 \\
\hline
\end{tabular}

$\mathrm{pH}$ was measured in 1:2.5 suspension; $\mathrm{EC}$ was measured in soil paste extract.

Table 2: Some properties of the applied compost (mean of two seasons):

\begin{tabular}{|c|c|c|c|c|c|c|c|c|c|c|}
\hline Properties & $\mathrm{pH}$ & $\begin{array}{c}\mathrm{EC} \\
\mathrm{dSm} \\
1\end{array}$ & $\begin{array}{c}\text { Moisture } \\
\%\end{array}$ & $\begin{array}{c}\text { Weight } \\
\text { of } \mathrm{m}^{3} \\
(\mathrm{~kg})\end{array}$ & $\begin{array}{c}\text { OM } \\
\%\end{array}$ & $\begin{array}{c}\text { Total } \\
\mathrm{C} \%\end{array}$ & $\begin{array}{c}\text { Total } \\
\mathrm{N} \%\end{array}$ & $\begin{array}{c}\mathrm{C}: \mathrm{N} \\
\text { ratio }\end{array}$ & $\begin{array}{c}\text { Total } \\
\mathrm{P} \%\end{array}$ & $\begin{array}{c}\text { Total } \\
\mathrm{K} \%\end{array}$ \\
\hline Values & 7.57 & 5.66 & 26 & 650 & 34.53 & 20.0 & 1.25 & $16: 1$ & 0.87 & 0.93 \\
\hline
\end{tabular}

$\mathrm{pH}$ was measured in 1: 10 suspension; $\quad \mathrm{EC}$ was measured in 1: 10 water extract.

The two experiments were designed in a split plot with three replicates; the plot area was $10.5 \mathrm{~m}^{2}$. The main plots received four treatment of compost without or with seed potato inoculation by bio-fertilizer that contains strains of K-release bacteria (KRB) "Bacillus circulans" (provided from the unit of bio-fertilizers at Soil, Water and Environment Research Institute, Agric. Res. Center, Giza, Egypt); as follows

1- $\operatorname{Org}_{1}: 10 \mathrm{~m}^{3}\left(6.5 \mathrm{t} \mathrm{fed}^{-1}\right)$ compost fed ${ }^{-1}$.

2- Org $_{1}+$ Bio: $10 \mathrm{~m}^{3}$ compost $\mathrm{fed}^{-1}+$ inoculation with bio-fertilizer.

3- $\operatorname{Org}_{2}: 20 \mathrm{~m}^{3}\left(13 \mathrm{tfed}^{-1}\right)$ compost fed ${ }^{-1}$.

4- $\mathrm{Org}_{2}+\mathrm{Bio}: 20 \mathrm{~m}^{3}$ compost $\mathrm{fed}^{-1}+$ inoculation with bio-fertilizer.

The sub plots received four treatments of $\mathrm{K}$ a soil and foliar application from two sources; K-sulfate (SOP) "48\% $\mathrm{K}_{2} \mathrm{O}$ " or feldspar (FDS) "10\% $\mathrm{K}_{2} \mathrm{O}$ " as follows: 1- $\mathrm{K} 1: 96 \mathrm{~kg} \mathrm{~K}_{2} \mathrm{O}$ fed $^{-1}$ as SOP (control).
2- $\mathrm{K} 2: 48 \mathrm{~kg} \mathrm{~K}_{2} \mathrm{O}$ fed $^{-1}$ as SOP $+1 \% \mathrm{~K}_{2} \mathrm{O}$ foliar as SOP.

3- $\mathrm{K} 3: 48 \mathrm{~kg} \mathrm{~K}_{2} \mathrm{O}$ fed $^{-1}$ as FDS $+1 \% \mathrm{~K}_{2} \mathrm{O}$ foliar as SOP.

4- $\mathrm{K} 4: 24 \mathrm{~kg} \mathrm{~K}_{2} \mathrm{O}$ fed $^{-1}$ as FDS $+1 \% \mathrm{~K}_{2} \mathrm{O}$ foliar as SOP.

\section{Application of fertilizers:}

The organic manure (compost) was applied before the last tillage, and then soil was irrigated 3 times before planting. Seed potato tubers were inoculated with effective bacteria just before planting.

Feldspar which is a natural rock of potassium contains about $10 \% \mathrm{~K}_{2} \mathrm{O}$ (as total) and was added to the soil with organic manure before planting. The rates of SOP was added to the soil in three equal doses, during preparation practices for cultivation and before fourth and eighth irrigation, while foliar treatment of $1 \% \quad \mathrm{~K}_{2} \mathrm{O}$ (SOP) was applied at 3 times; after complete 
emergency then at 15 days intervals (spraying solution volume was $400 \mathrm{~L} \mathrm{fed}^{-1}$ ).

All plots received the recommended rates of $\mathrm{N}$ and $\mathrm{P}$ fertilizers. Nitrogen fertilizer was applied at $150 \mathrm{~kg} \mathrm{~N}^{-1}$ as ammonium nitrate $(33.5 \% \mathrm{~N})$ in eight equal doses weekly starting from the first irrigation after emergency. Phosphorus fertilizer was added during soil preparation before planting at the rate of $75 \mathrm{~kg}^{\mathrm{P}_{2} \mathrm{O}_{5}} \mathrm{fed}^{-1}$ as $\mathrm{Ca}$ superphosphate $\left(15 \% \mathrm{P}_{2} \mathrm{O}_{5}\right)$.

Drip irrigation system was used where irrigation laterals were $16 \mathrm{~mm}$ in diameter and 30 meter length have in line emitters (drippers) spaced $0.3 \mathrm{~m}$ apart with $3.6 \mathrm{~L} \mathrm{~h}^{-1}$ flow rate at pressure of $100 \mathrm{kpa}$.

\section{Planting and harvest:}

Seed potato tubers were planted on $1^{\text {st }}$ December 2013 in $1^{\text {st }}$ season and harvested on $2^{\text {nd }}$ April 2014, while in $2^{\text {nd }}$ season seed potato tuber were planted on $3^{\text {rd }}$ December 2014 and harvested on $4^{\text {th }}$ April 2015. At 90 days from planting plant height $(\mathrm{cm})$ and shoot fresh weight ( $\mathrm{g} \mathrm{plant}^{-1}$ ) were recorded. At harvest, the following parameters were recorded: (1) shoot dry yield $\left(\mathrm{t} \mathrm{fed}^{-1}\right)$, tuber yield/Plant $\left(\mathrm{kg} \mathrm{plant}^{-1}\right)$, average tuber weight (g) and total tuber yield $\left(\mathrm{t}_{\text {fed }}{ }^{-1}\right)$. (2) Tuber quality parameters: dry matter $\%$, specific gravity, starch \%, protein \%, carbohydrate $\%$ and reducing sugar \% (A.O.A.C., 1990). (3) $\mathrm{N}, \mathrm{P}$ and $\mathrm{K} \%$ were determined in tuber dry matter according to A.O.A.C. (1990); and NPK uptake in tuber was then calculated $(\mathrm{kg}$ fed $^{-1}$ ).

Specific gravity $=$ (tuber weight in the air) / (tuber weight in the air - tuber weight in the water), (Smith, 1975).

Starch \% $=17.457+(0.89 \times($ dry matter $\%$ 24), (Burton, 1948).

Protein $\%=N \%$ in tuber $\times 6.25$, (Ranganna, 1977).

(4) Profitability was calculated as net return and investment factor as follows.
Gross return (GR), L.E = yield price (tuber yield $t$ fed $^{-1} \times$ price $\left.^{-1}\right)$.

Net return (NR), L.E $=$ (gross return- total cost).

Investment factor (IF) = gross return (L.E.)/total cost (L.E.).

The statistical analysis of the obtained data was done according to the methods described by Gomez and Gomez (1984) using LSD to compare the means of treatments values at $5 \%$.

\section{RESULTS AND DISCUSSION \\ 1- Growth, Yield and Its Components. \\ Plant growth parameters:}

Data in Table 3 show that shoot fresh weight/plant after 90 days and shoot dry weight (t. $\mathrm{fed}^{-1}$ ) at harvest significantly increased with addition of K-treatments at 48 $\mathrm{kg} \mathrm{K}_{2} \mathrm{O}$ fed $^{-1}$ as SOP or FDS with foliar $1 \%$ $\mathrm{K}_{2} \mathrm{O}$ compared to $\mathrm{K}$-recommended $(\mathrm{RK})$ rate $\left(96 \mathrm{~kg} \mathrm{~K}_{2} \mathrm{O}\right.$ fed $^{-1}$ ) in favor of FDS showing that $50 \%$ of RK could be saved by foliar $1 \%$ $\mathrm{K}_{2} \mathrm{O}$. These effects may be attributed to the uniform distribution of nutrients in foliar sprays and less likelihood that the nutrients will be washed off before absorption occurs on the other hand the promotive effect of $\mathrm{K}$ may be due to the role of $\mathrm{K}$ in translocation of metabolized materials from shoot to tubers (storage parts) and correlation between the amount of K-applied and the rate of translocation from shoot to tubers. These results agreed with El-Sawy et al., (2000).

Also, data in the same table reveal that increasing compost level from 10 to $20 \mathrm{~m}^{3}$ $\mathrm{fed}^{-1}$ with or without K-release bacteria (KRB) significantly increased plant height, shoot fresh weight plant $^{-1}$ and shoot dry weight $\mathrm{fed}^{-1}$, and the highest values were $48.5 \mathrm{~cm}, 331 \mathrm{~g} \mathrm{plant}^{-1}$ and $1.656 \mathrm{t} \mathrm{fed}^{-1}$ with treatment $20 \mathrm{~m}^{3}$ compost with bioinoculation $\left(\mathrm{Org}_{2}+\mathrm{Bio}\right)$ for pervious parameters, respectively. 
Table 3: Effect of compost, K-release bacteria, K-treatments as SOP or feldspar with foliar $K$ and their interactions on potato growth, yield and its components (Average of two growing seasons).

\begin{tabular}{|c|c|c|c|c|c|c|c|}
\hline \multirow{2}{*}{\multicolumn{2}{|c|}{$\begin{array}{l}\text { Characteristics } \\
\text { Treatments }\end{array}$}} & $\begin{array}{l}\text { Shoot fresh } \\
\text { weight } \\
\left.\text { (g plant }^{-1}\right)\end{array}$ & $\begin{array}{l}\text { Plant } \\
\text { height } \\
\text { (cm) }\end{array}$ & $\begin{array}{l}\text { Shoot } \\
\text { dry } \\
\text { weight } \\
\left(\mathrm{t} \mathrm{fed}^{-1}\right)\end{array}$ & $\begin{array}{l}\text { Tuber yield } \\
(\mathrm{kg} \text { plant }\end{array}$ & $\begin{array}{l}\text { Average } \\
\text { weight of } \\
\text { tuber (g) }\end{array}$ & $\begin{array}{c}\text { Tuber } \\
\text { yield } \\
\left(\mathrm{t} \mathrm{fed}^{-1}\right)\end{array}$ \\
\hline & & \multicolumn{2}{|c|}{ At 90 days } & \multicolumn{4}{|c|}{ At harvest } \\
\hline \multicolumn{8}{|c|}{ Organic \pm Bio-fertilizer treatments } \\
\hline & $297^{c}$ & $42.17^{c}$ & $1.485^{\mathrm{C}}$ & $0.880^{\mathrm{b}}$ & $179^{c}$ & $15.376^{b}$ \\
\hline & & $301^{\mathrm{c}}$ & $46.17^{\mathrm{b}}$ & $1.505^{\mathrm{C}}$ & $0.915^{\mathrm{ab}}$ & $193^{b}$ & $15.622^{b}$ \\
\hline \multicolumn{2}{|c|}{$\begin{array}{c}\operatorname{Org}_{1}+\text { Bio } \\
\operatorname{Org}_{2}\end{array}$} & $325^{b}$ & $47.75^{a}$ & $1.627^{b}$ & $0.925^{\mathrm{a}}$ & $198^{\mathrm{ab}}$ & $16.179^{\mathrm{a}}$ \\
\hline \multicolumn{2}{|c|}{$\mathrm{Org}_{2}+\mathrm{Bio}$} & $331^{a}$ & $48.50^{\mathrm{a}}$ & $1.656^{\mathrm{a}}$ & $0.938^{\mathrm{a}}$ & $207^{a}$ & $16.404^{\mathrm{a}}$ \\
\hline \multicolumn{2}{|c|}{ LSD at $5 \%$} & 4.8 & 1.12 & 0.024 & 0.008 & 9.14 & 0.288 \\
\hline \multicolumn{8}{|c|}{ K-treatments } \\
\hline \multicolumn{2}{|c|}{ K1 } & $289^{c}$ & $47.33^{b}$ & $1.446^{\mathrm{C}}$ & $0.932^{\mathrm{a}}$ & $196^{a}$ & $16.150^{2}$ \\
\hline \multicolumn{2}{|c|}{ K2 } & $314^{b}$ & $49.75^{a}$ & $1.570^{b}$ & $0.933^{\mathrm{a}}$ & $198^{\mathrm{a}}$ & $16.169^{\mathrm{a}}$ \\
\hline \multicolumn{2}{|c|}{ K3 } & $323^{a}$ & $44.25^{\mathrm{c}}$ & $1.617^{\mathrm{a}}$ & $0.918^{a}$ & $198^{\mathrm{a}}$ & $15.825^{b}$ \\
\hline \multicolumn{2}{|c|}{ K4 } & $328^{a}$ & $43.25^{\mathrm{c}}$ & $1.640^{\mathrm{a}}$ & $0.874^{c}$ & $184^{\mathrm{b}}$ & $15.437^{\circ}$ \\
\hline \multicolumn{2}{|c|}{ LSD at $5 \%$} & 6.7 & 1.05 & 0.034 & 0.009 & 9.78 & 0.244 \\
\hline \multicolumn{8}{|c|}{ Interaction effects } \\
\hline \multirow{4}{*}{$\operatorname{Org}_{1}$} & $\mathrm{~K} 1$ & 284 & 42.67 & 1.422 & 0.923 & 185 & 15.710 \\
\hline & $\mathrm{K} 2$ & 299 & 45.33 & 1.497 & 0.920 & 184 & 15.693 \\
\hline & K3 & 303 & 40.33 & 1.515 & 0.902 & 180 & 15.243 \\
\hline & K4 & 301 & 40.33 & 1.507 & 0.773 & 168 & 14.857 \\
\hline \multirow{4}{*}{$\underset{\mathrm{Bio}}{\mathrm{Org}_{1}+}$} & $\mathrm{K} 1$ & 285 & 47.00 & 1.423 & 0.925 & 196 & 15.803 \\
\hline & $\mathrm{K} 2$ & 295 & 48.67 & 1.477 & 0.927 & 199 & 15.890 \\
\hline & K3 & 300 & 45.00 & 1.500 & 0.913 & 198 & 15.577 \\
\hline & K4 & 324 & 44.00 & 1.620 & 0.893 & 179 & 15.217 \\
\hline \multirow{4}{*}{$\operatorname{Org}_{2}$} & $\mathrm{~K} 1$ & 290 & 49.33 & 1.448 & 0.933 & 201 & 16.403 \\
\hline & $\mathrm{K} 2$ & 326 & 52.00 & 1.630 & 0.936 & 201 & 16.397 \\
\hline & K3 & 346 & 45.33 & 1.730 & 0.920 & 203 & 16.160 \\
\hline & $\mathrm{K} 4$ & 340 & 44.33 & 1.698 & 0.910 & 189 & 15.757 \\
\hline \multirow{4}{*}{$\begin{array}{c}\mathrm{Org}_{2}+ \\
\mathrm{Bio}\end{array}$} & $\mathrm{K} 1$ & 298 & 50.33 & 1.490 & 0.947 & 205 & 16.683 \\
\hline & $\mathrm{K} 2$ & 335 & 53.00 & 1.675 & 0.950 & 210 & 16.697 \\
\hline & K3 & 344 & 46.33 & 1.722 & 0.937 & 213 & 16.320 \\
\hline & K4 & 347 & 44.33 & 1.737 & 0.920 & 201 & 15.917 \\
\hline \multicolumn{2}{|c|}{ LSD at $5 \%$} & 13.5 & ns & 0.068 & 0.019 & Ns & ns \\
\hline
\end{tabular}

$\mathrm{Org}_{1}=10 \mathrm{~m}^{3}$ compost fed ${ }^{-1} ; \mathrm{Org}_{2}=20 \mathrm{~m}^{3}$ compost fed ${ }^{-1} ; \quad \mathrm{Bio}=$ inoculation by K-release bacteria; $\mathrm{K} 1=96 \mathrm{~kg} \mathrm{~K}_{2} \mathrm{O} \mathrm{fed}^{-1} ; \quad \mathrm{K} 2=48 \mathrm{~kg} \mathrm{~K}_{2} \mathrm{O}$ fed ${ }^{-1}+1 \% \mathrm{~K}_{2} \mathrm{O}$ foliar; $\mathrm{K} 3=48 \mathrm{~kg} \mathrm{~K}_{2} \mathrm{O}$ fed ${ }^{-1}$ as feldspar $+1 \% \mathrm{~K}_{2} \mathrm{O}$ foliar; $\mathrm{K} 4=24 \mathrm{~kg} \mathrm{~K}_{2} \mathrm{O}$ fed $^{-1}$ as feldspar $+1 \% \mathrm{~K}_{2} \mathrm{O}$ foliar. 
Concerning the effect of interaction between compost levels with or without KRB and different $\mathrm{K}$ treatments, data show that interactions have significant effects on shoot fresh weight per plant and shoot dry weight per fed., and insignificant effect on plant height. The values of plant height, shoot fresh and dry weight were higher under interaction $\mathrm{Org}_{2}+\mathrm{Bio}^{*} \mathrm{~K}$ than other interactions. These results are in accordance with El-Sayed et al., (2014).

\section{Potato yield and its components:}

Data in Table 3 indicated that addition of K-treatments have a significant effect on tuber yield/plant, average tuber weight and total tuber yield (t. fed ${ }^{-1}$ ). However, no significant differences in average tuber weight, tuber yield plant ${ }^{-1}$ or tuber yield fed ${ }^{-1}$ were detected between the RK and K2 (48 $\mathrm{kg} \mathrm{K}_{2} \mathrm{O}$ as SOP + foliar $1 \% \mathrm{~K}_{2} \mathrm{O}$ ), while these parameters were significantly reduced by using FDS instead of SOP compared with RK with $2 \%$ and $4.4 \%$ reduction in tuber yield fed ${ }^{-1}$ due to $\mathrm{K} 3$ and $\mathrm{K} 4$ respectively. Also, applying of $24 \mathrm{~kg} \mathrm{~K}_{2} \mathrm{O}$ fed ${ }^{-1}$ as FDS+ foliar $1 \% \mathrm{~K}_{2} \mathrm{O}$ recorded significant reduction in average tuber weight by about $6 \%$ compared with RK. This effect may be attributed to the slow released $\mathrm{K}$ from FDS with insufficient available $\mathrm{K}$ for potato growth. These results are in accordance with those of Gomaa (2007), El-Dissoky (2008) and Singh and Lal (2012) who found that tuber yield responded significantly to foliar spray of $1 \% \mathrm{~K}_{2} \mathrm{O}$ with soil application of 24, 36 and $48 \mathrm{~kg} \mathrm{~K}_{2} \mathrm{O}$ fed $^{-1}$.

Also, data show that increasing compost level application from 10 to $20 \mathrm{~m}^{3} \mathrm{fed}^{-1}$ significantly increased tuber yield per feddan by about $5 \%$ with or without inoculation, and average tuber weight by $10.6 \%$ and $7.2 \%$ with and without bio-fertilization, respectively, and tuber yield per plant by 5.1 $\%$ and $2.5 \%$ with and without biofertilization, respectively with no significant effect for the bio-fertilizer on tuber yield. The highest value of tuber yield per feddans was
$16.404 \mathrm{t}^{- \text {fed }^{-1}}$ at treatment $\mathrm{Org}_{2}+\mathrm{Bio}$. These results may be due to the positive effects of compost as organic fertilizer on physical and chemical properties of the sandy soil that considers poor in organic matter (as shown in Table 1), in addition to the role of $\mathrm{K}$ release bacteria and its effect on biological properties of sandy soil under study which reflected on the tuber yield. These results are in harmony with those of El-Sayed et al., (2014).

Data also reveal that the effect of interaction among the studied treatments was significant for plant tuber yield only, and insignificant for average tuber weight and total tuber yield. The highest values were recorded with the inoculated composted plots $\left(20 \mathrm{~m}^{3} \mathrm{fed}^{-1}\right)$ combined with soil application of half recommended $\mathrm{K}$-rate as SOP along with foliar spray of $1 \% \mathrm{~K}_{2} \mathrm{O}$. The highest tuber yield was $16.697 \mathrm{t}^{\mathrm{t}} \mathrm{fed}^{-1}$ with interaction $\mathrm{Org}_{2}+\mathrm{Bio}^{*} \mathrm{~K} 2$ and was on bar with that of the RK (K1) showing that $50 \%$ of RK could be saved by using this interaction. These results are agreeable with those obtained by Gomaa (2007), Abo El-Khair et al., (2009) and Shehata et al., (2014).

\section{2- Tubers Quality:}

As shown in Table 4, data illustrate that foliar addition of $1 \% \mathrm{~K}_{2} \mathrm{O}$ with $50 \%$ soil addition of recommended $\mathrm{K}$ as SOP or feldspar have significant effects on the studied parameters of tuber quality except reducing sugar \% which was insignificantly affected. It is obvious that values of tuber quality parameters were superior under $\mathrm{K} 2$ (50\% of Rd-K as SOP $+1 \% \mathrm{~K}_{2} \mathrm{O}$ foliar) and K3 (50\% of Rd-K as feldspar+ $1 \% \mathrm{~K}_{2} \mathrm{O}$ foliar) compared with control with no significant difference between the two treatments. Since the values of tuber quality that recorded under K2 and K3 were 19.0 and $19.08 \%$ for dry matter \% (DM), 1.086 and 1.091 for specific gravity (SG) and 12.93 and $13.0 \%$ for starch \% (St), respectively. Generally, tuber quality improved with increasing DM\%, SG, St\% and carbohydrate $\%$, and decreased with 
increasing reducing sugar $\%$. The positive

in accordance with Labib et al., (2012).

effect of addition K-rates on tuber quality is

Table 4: Effect of compost, K-release bacteria, K-treatments as SOP or feldspar with foliar $K$ and their interactions on tuber quality parameters (Average of two growing seasons).

\begin{tabular}{|c|c|c|c|c|c|c|c|}
\hline \multicolumn{2}{|c|}{ Treatments } & $\begin{array}{c}\text { Dry } \\
\text { matter } \\
\%\end{array}$ & $\begin{array}{l}\text { Specific } \\
\text { gravity }\end{array}$ & $\begin{array}{c}\text { Starch } \\
\%\end{array}$ & $\begin{array}{l}\text { Carbohydr- } \\
\text { ate } \%\end{array}$ & $\begin{array}{l}\text { Reducing } \\
\text { sugar \% }\end{array}$ & $\begin{array}{c}\text { Protein } \\
\%\end{array}$ \\
\hline \multicolumn{8}{|c|}{ Organic \pm Bio-fertilizer treatments } \\
\hline \multicolumn{2}{|c|}{$\mathrm{Org}_{1}$} & $17.89^{b}$ & $1.079^{b}$ & $11.94^{b}$ & $77.13^{\mathrm{ab}}$ & $2.76^{a}$ & $14.73^{b}$ \\
\hline \multicolumn{2}{|c|}{$\mathrm{Org}_{1}+\mathrm{Bio}$} & $19.38^{\mathrm{a}}$ & $1.089^{\mathrm{a}}$ & $13.27^{\mathrm{a}}$ & $77.99^{\mathrm{a}}$ & $2.78^{\mathrm{a}}$ & $14.32^{\mathrm{c}}$ \\
\hline \multicolumn{2}{|c|}{$\operatorname{Org}_{2}$} & $18.97^{\mathrm{a}}$ & $1.090^{\mathrm{a}}$ & $12.90^{\mathrm{a}}$ & $76.18^{\mathrm{C}}$ & $2.66^{a}$ & $14.95^{\mathrm{ab}}$ \\
\hline \multicolumn{2}{|c|}{$\mathrm{Org}_{2}+\mathrm{Bio}$} & $19.18^{a}$ & $1.091^{\mathrm{a}}$ & $13.09^{a}$ & $76.76^{\mathrm{bc}}$ & $2.77^{\mathrm{a}}$ & $15.29^{a}$ \\
\hline \multicolumn{2}{|c|}{ LSD at $5 \%$} & 0.66 & 0.006 & 0.59 & 0.94 & ns & 0.35 \\
\hline \multicolumn{8}{|c|}{ K-treatments } \\
\hline \multicolumn{2}{|c|}{ K1 } & $18.42^{b}$ & $1.084^{\mathrm{C}}$ & $12.41^{\mathrm{b}}$ & $76.83^{b}$ & $2.75^{a}$ & $14.62^{b}$ \\
\hline \multicolumn{2}{|c|}{ K2 } & $19.00^{\mathrm{a}}$ & $1.086^{b c}$ & $12.93^{a}$ & $78.14^{\mathrm{a}}$ & $2.80^{a}$ & $15.40^{\mathrm{a}}$ \\
\hline \multicolumn{2}{|c|}{ K3 } & $19.08^{a}$ & $1.091^{\mathrm{a}}$ & $13.00^{\mathrm{a}}$ & $76.88^{b}$ & $2.68^{a}$ & $14.86^{\mathrm{b}}$ \\
\hline \multicolumn{2}{|c|}{ K4 } & $18.92^{\mathrm{a}}$ & $1.088^{\mathrm{ab}}$ & $12.86^{a}$ & $76.21^{b}$ & $2.74^{\mathrm{a}}$ & $14.41^{\mathrm{b}}$ \\
\hline \multicolumn{2}{|c|}{ LSD at $5 \%$} & 0.39 & 0.004 & 0.35 & 0.81 & ns & 0.52 \\
\hline \multicolumn{8}{|c|}{ Interaction effects } \\
\hline \multirow{4}{*}{$\operatorname{Org}_{1}$} & $\mathrm{~K} 1$ & 16.95 & 1.066 & 11.10 & 76.47 & 2.81 & 14.96 \\
\hline & $\mathrm{K} 2$ & 18.71 & 1.074 & 12.67 & 78.03 & 2.99 & 16.07 \\
\hline & K3 & 17.36 & 1.089 & 11.47 & 76.87 & 2.47 & 14.11 \\
\hline & $\mathrm{K} 4$ & 18.52 & 1.086 & 12.51 & 77.17 & 2.78 & 13.79 \\
\hline \multirow{4}{*}{$\begin{array}{c}\operatorname{Org}_{1}+ \\
\text { Bio }\end{array}$} & $\mathrm{K} 1$ & 19.31 & 1.087 & 13.21 & 77.93 & 2.84 & 14.54 \\
\hline & $\mathrm{K} 2$ & 19.88 & 1.087 & 13.72 & 80.13 & 2.78 & 14.28 \\
\hline & $\mathrm{K} 3$ & 19.22 & 1.092 & 13.13 & 77.07 & 2.71 & 14.30 \\
\hline & $\mathrm{K} 4$ & 19.11 & 1.088 & 13.03 & 76.83 & 2.79 & 14.14 \\
\hline \multirow{4}{*}{$\operatorname{Org}_{2}$} & $\mathrm{~K} 1$ & 18.99 & 1.092 & 12.92 & 76.57 & 2.68 & 13.77 \\
\hline & K2 & 17.84 & 1.092 & 11.90 & 77.90 & 2.65 & 15.68 \\
\hline & K3 & 19.87 & 1.092 & 13.71 & 75.83 & 2.66 & 16.15 \\
\hline & K4 & 19.17 & 1.086 & 13.09 & 74.40 & 2.67 & 14.21 \\
\hline \multirow{4}{*}{$\begin{array}{c}\mathrm{Org}_{2}+ \\
\text { Bio }\end{array}$} & $\mathrm{K} 1$ & 18.42 & 1.090 & 12.41 & 76.33 & 2.68 & 15.21 \\
\hline & $\mathrm{K} 2$ & 19.56 & 1.092 & 13.43 & 76.50 & 2.78 & 15.59 \\
\hline & K3 & 19.87 & 1.090 & 13.71 & 77.77 & 2.87 & 14.88 \\
\hline & K4 & 18.87 & 1.092 & 12.82 & 76.43 & 2.73 & 15.49 \\
\hline \multicolumn{2}{|c|}{ LSD at $5 \%$} & 0.79 & 0.008 & 0.70 & 1.62 & Ns & 1.04 \\
\hline
\end{tabular}

$\operatorname{Org}_{1}=10 \mathrm{~m}^{3}$ compost fed ${ }^{-1} ; \quad \operatorname{Org}_{2}=20 \mathrm{~m}^{3}$ compost fed ${ }^{-1} ; \quad$ Bio $=$ inoculation by K-release bacteria;

$\mathrm{K} 1=96 \mathrm{~kg} \mathrm{~K}_{2} \mathrm{O} \mathrm{fed}^{-1} ; \quad \mathrm{K} 2=48 \mathrm{~kg} \mathrm{~K}_{2} \mathrm{O}$ fed ${ }^{-1}+1 \% \mathrm{~K}_{2} \mathrm{O}$ foliar; $\mathrm{K} 3=48 \mathrm{~kg} \mathrm{~K}_{2} \mathrm{O} \mathrm{fed}{ }^{-1}$ as feldspar $+1 \% \mathrm{~K}_{2} \mathrm{O}$ foliar; $\mathrm{K} 4=24 \mathrm{~kg} \mathrm{~K}_{2} \mathrm{O}$ fed ${ }^{-1}$ as feldspar $+1 \% \mathrm{~K}_{2} \mathrm{O}$ foliar. 
Concerning the effect of compost along with Bio-inoculation by $\mathrm{K}$ release bacteria, it is obvious from the results in Table 4 that these treatments have significant effects on tuber quality parameters, except reducing sugar \% which was insignificantly affected. Inoculation with K-release bacteria with addition of compost levels $\left(\mathrm{Org}_{1}\right.$ or $\mathrm{Org}_{2}$ ) was more effective on DM, SG, St, carbohydrate $\%$ and protein $\%$. This positive effect may be attributed to the effect of compost and Bio-inoculation on soil properties and plant growth, yield and consequently on tubers quality. These results are in agreement with Makaraviciute (2003) and El-Sayed et al., (2014).

Also, data in the same table indicate that the effect of interaction among Org \pm Bio and K-treatments was significant on DM, $\mathrm{SG}, \mathrm{St} \%, \mathrm{Ch} \%$ and protein \%, but insignificant on reducing sugar $\%$. The interactions of $\operatorname{Org}_{1}+\mathrm{Bio}^{*} \mathrm{~K} 2, \mathrm{Org}_{2}+\mathrm{Bio}^{*} \mathrm{~K} 2$ and $\mathrm{Org}_{2}+\mathrm{Bio}^{*} \mathrm{~K} 3$ were superior in its effects on mostly of tuber quality parameters. This effect may be attributed to the integration effect that happened through organic manure (compost) effect, beneficial effect of $\mathrm{K}$-release bacteria and the important role of $\mathrm{K}$ in plant growth. Similar observations were obtained by Ali (2006) and Abo El-Khair et al., (2009) who found that inoculation with $B$. circulans in the presence of K-sources (Ksulfate and feldspar) increased potato tuber content of carbohydrate and soluble sugars.

\section{3- $N, P$ and $K$ uptake in tubers:}

Data in Table 5 show that application of $50 \%$ RDK as SOP or feldspar with foliar spray of $1 \% \mathrm{~K}_{2} \mathrm{O}$ have significant effect on $\mathrm{N}$ and K-uptake and insignificant effect on $\mathrm{P}$ uptake. The highest values of $\mathrm{N}, \mathrm{P}$ and $\mathrm{K}$ uptake were recorded under $\mathrm{K} 2$ ( $50 \%$ of RK as SOP $+1 \% \mathrm{~K}_{2} \mathrm{O}$ foliar) and $\mathrm{K} 3(50 \%$ of $\mathrm{RK}$ as feldspar $+1 \% \mathrm{~K}_{2} \mathrm{O}$ foliar). The significant effect of soil combined with foliar $\mathrm{K}$ application as $\mathrm{K}$-sulfate or feldspar on $\mathrm{K}$ uptake may be related to the important role of $\mathrm{K}$ in plant especially in tubers where $\mathrm{K}$ is a high consumption element for potato (ALMoshileh and Errebi, 2004). These results are in accordance with those obtained by Ali (2006), Gomaa (2007).

Also, data in the same table reveal that increasing level of compost from 10 to $20 \mathrm{~m}^{3}$ $\mathrm{fed}^{-1}$ with or without Bio-fertilizer have significant effects on N, P and K-uptake in tuber, where the highest values of $\mathrm{N}, \mathrm{P}$ and K-uptake were $91.7,8.19$ and $81.2 \mathrm{~kg} \mathrm{fed}^{-1}$ respectively with $\mathrm{Org}_{2}+\mathrm{Bio}\left(20 \mathrm{~m}^{3}\right.$ compost $\left.\mathrm{fed}^{-1}+\mathrm{Bio}\right)$. This significant effect of compost and bio-fertilizer may be return to the integration effect of organic manure (compost) and bio-fertilizer that reflected on availability of $\mathrm{N}, \mathrm{P}$ and $\mathrm{K}$ in soil and its content of these nutrients especially $\mathrm{K}$, which reflected consequently on its uptake by plants (Abo El-Khair et al., 2009 and ElSayed 2014). In addition to this, it is well known that many organic compounds produced by microorganisms, such as acetate, citrate and oxalate which can increase mineral dissolution rate (Welch and Ullman, 1993), also microorganisms produced growth promoting substance, which increase plant growth, then tuber yield, nutrient uptake and quality of tuber (Abou Hussein et al., 2002).

Regarding the effect of interaction on $\mathrm{N}$, $\mathrm{P}$ and K-uptake, Data presented in Table 5 illustrate that $\mathrm{N}$ and K-uptake were significantly affected by interaction between compost with or without K-release bacteria and different treatments of $\mathrm{K}$ application, while P-uptake was insignificantly affected. It is obvious from those results that all values of $\mathrm{N}, \mathrm{P}$ and $\mathrm{K}$-uptake in tubers were higher under interactions among $\mathrm{Org}_{2}+\mathrm{Bio}$ and $\mathrm{K}$ treatments ( $\mathrm{K} 1, \mathrm{~K} 2, \mathrm{~K} 3$ and $\mathrm{K} 4)$, since the superiority was for interactions $\mathrm{Org}_{2}+\mathrm{Bio}^{*} \mathrm{~K} 2$ and $\mathrm{Org}_{2}+\mathrm{Bio}^{*} \mathrm{~K} 3$. These results may be due to integration effect between compost and $\mathrm{K}$-release bacteria ( $B$. circulans) and $\mathrm{K}$ sources (K-sulfate and feldspar) on soil, which reflected on soil physical, chemical and biological properties and availability of 
$\mathrm{N}, \mathrm{P}$ and $\mathrm{K}$, and consequently on plant growth and its uptake of NPK and other nutrients, also it is related with the effect of
Bio-inoculation in increasing release of $\mathrm{K}$ on soil (Abo El-Khair et al., 2009 and Shehata et al., 2014).

Table 5: Effect of compost, K-release bacteria, K-treatments as SOP or feldspar with foliar $\mathrm{K}$ and their interactions on $\mathrm{N}, \mathrm{P}$ and $\mathrm{K}$ uptake in tuber yield (Average of two growing seasons).

\begin{tabular}{|c|c|c|c|c|}
\hline \multicolumn{2}{|c|}{ Treatments } & $\begin{array}{l}\text { N-uptake } \\
\left(\mathrm{kg} \mathrm{fed}^{-1}\right)\end{array}$ & $\begin{array}{l}\text { P-uptake } \\
\left(\mathrm{kg} \mathrm{fed}^{-1}\right)\end{array}$ & $\begin{array}{l}\text { K-uptake } \\
\left(\mathrm{kg} \mathrm{fed}^{-1}\right)\end{array}$ \\
\hline \multicolumn{5}{|c|}{ Organic \pm Bio-fertilizer treatments } \\
\hline \multicolumn{2}{|c|}{$\operatorname{Org}_{1}$} & $77.3^{\mathrm{c}}$ & $6.67^{b}$ & $65.1^{\mathrm{c}}$ \\
\hline \multicolumn{2}{|c|}{$\operatorname{Org}_{1}+$ Bio } & $82.6^{b c}$ & $7.78^{\mathrm{a}}$ & $75.9^{b}$ \\
\hline \multicolumn{2}{|c|}{$\mathrm{Org}_{2}$} & $87.4^{\mathrm{ab}}$ & $7.73^{\mathrm{a}}$ & $78.4^{\mathrm{ab}}$ \\
\hline \multicolumn{2}{|c|}{$\mathrm{Org}_{2}+\mathrm{Bio}$} & $91.7^{\mathrm{a}}$ & $8.19^{a}$ & $81.2^{\mathrm{a}}$ \\
\hline \multicolumn{2}{|c|}{ LSD at $5 \%$} & 5.9 & 0.49 & 3.95 \\
\hline \multicolumn{5}{|l|}{ K-treatments } \\
\hline \multicolumn{2}{|l|}{$\mathrm{K} 1$} & $82.8^{\mathrm{bc}}$ & $7.59^{\mathrm{ab}}$ & $74.4^{\mathrm{b}}$ \\
\hline \multicolumn{2}{|c|}{ K2 } & $90.1^{\mathrm{a}}$ & $7.93^{\mathrm{a}}$ & $77.2^{\mathrm{a}}$ \\
\hline \multicolumn{2}{|c|}{ K3 } & $85.9^{\mathrm{ab}}$ & $7.71^{\mathrm{ab}}$ & $77.2^{\mathrm{a}}$ \\
\hline \multicolumn{2}{|c|}{ K4 } & $80.3^{\mathrm{c}}$ & $7.15^{\mathrm{b}}$ & $72.0^{c}$ \\
\hline \multicolumn{2}{|c|}{ LSD at $5 \%$} & 4.36 & ns & 2.22 \\
\hline \multicolumn{5}{|l|}{ Interaction effects } \\
\hline \multirow{4}{*}{$\operatorname{Org}_{1}$} & K1 & 75.9 & 6.77 & 63.4 \\
\hline & K2 & 89.8 & 7.42 & 69.6 \\
\hline & K3 & 71.1 & 6.34 & 62.4 \\
\hline & K4 & 72.3 & 6.15 & 65.1 \\
\hline \multirow{4}{*}{$\mathrm{Org}_{1}+\mathrm{Bio}$} & $\mathrm{K} 1$ & 84.7 & 7.72 & 74.7 \\
\hline & K2 & 85.9 & 8.49 & 81.5 \\
\hline & K3 & 81.6 & 7.60 & 75.5 \\
\hline & K4 & 78.3 & 7.31 & 72.0 \\
\hline \multirow{4}{*}{$\operatorname{Org}_{2}$} & $\mathrm{~K} 1$ & 81.7 & 8.00 & 80.1 \\
\hline & K2 & 87.4 & 7.29 & 73.6 \\
\hline & K3 & 98.9 & 8.39 & 84.4 \\
\hline & K4 & 81.8 & 7.23 & 75.5 \\
\hline \multirow{4}{*}{$\mathrm{Org}_{2}+$ Bio } & K1 & 89.0 & 7.86 & 79.3 \\
\hline & $\mathrm{K} 2$ & 97.1 & 8.50 & 84.0 \\
\hline & K3 & 91.9 & 8.49 & 86.4 \\
\hline & K4 & 88.6 & 7.92 & 75.2 \\
\hline \multicolumn{2}{|c|}{ LSD at $5 \%$} & 8.72 & ns & 4.44 \\
\hline
\end{tabular}

$\mathrm{Org}_{1}=10 \mathrm{~m}^{3}$ compost fed $^{-1} ; \quad \operatorname{Org}_{2}=20 \mathrm{~m}^{3}$ compost fed ${ }^{-1} ; \quad$ Bio= inoculation by K-release bacteria;

$\mathrm{K} 1=96 \mathrm{~kg} \mathrm{~K}_{2} \mathrm{O} \mathrm{fed}^{-1} ; \quad \mathrm{K} 2=48 \mathrm{~kg} \mathrm{~K}_{2} \mathrm{O}$ fed $^{-1}+1 \% \mathrm{~K}_{2} \mathrm{O}$ foliar; $\mathrm{K} 3=48 \mathrm{~kg} \mathrm{~K}_{2} \mathrm{O}$ fed $^{-1}$ as feldspar $+1 \% \mathrm{~K}_{2} \mathrm{O}$ foliar; $\mathrm{K} 4=24 \mathrm{~kg} \mathrm{~K}_{2} \mathrm{O}$ fed ${ }^{-1}$ as feldspar $+1 \% \mathrm{~K}_{2} \mathrm{O}$ foliar. 


\section{4- Economic Evaluation:}

Data in Table 6 show total costs (TC), gross return (GR), net return (NR) and investment factor (IF) for potato tuber yield at different treatments. In this study, it would be pointed out to inputs and outputs as follows:

1- The inputs were as follows:

L.E. 5600 for ton of SOP (280 L.E/50 kg).

L.E. 350 for ton of feldspar.

L.E. 160 for $\mathrm{m}^{3}$ of compost.

L.E. 50 for labor/day.

L.E. 320 for K-foliar (3 times).

L.E.10000 Constant costs (the costs of seeds, super phosphate fertilizer, ammonium nitrate fertilizer and any other practices).
2- The outputs were: L.E. 1500 , for ton of potato.

Data in Table 6 and Fig. 1 illustrate the effect of K-treatments on NR and IF. Results show that values of NR and total tubers yield were the highest under $\mathrm{K} 2$, while $\mathrm{K} 3$ recorded the highest IF. As for NR, the descending order of $\mathrm{K}$ treatments effect was as follows $\mathrm{K} 2>\mathrm{K} 3>\mathrm{K} 1>\mathrm{K} 4$, and for IF K3 $>\mathrm{K} 2=\mathrm{K} 4>\mathrm{K} 1$, but the arrangement for total tubers yield was $\mathrm{K} 2>\mathrm{K} 1>\mathrm{K} 3>\mathrm{K} 4$. Soil application of $50 \%$ of K-recommended as K-sulfate or feldspar with foliar spray ( 3 times) with $1 \% \mathrm{~K}_{2} \mathrm{O}(\mathrm{K} 2$ and $\mathrm{K} 3$ ) recorded the highest values of NR (10859 and 10835 L.E) and of IF (1.81 and 1.84), respectively.

Table 6: Economic evaluation of different treatments on total potato tuber yield (Average of two growing seasons).

\begin{tabular}{|c|c|c|c|c|c|c|c|c|c|c|c|c|}
\hline \multicolumn{2}{|c|}{ Treatments } & \multirow{2}{*}{$\begin{array}{c}\begin{array}{c}\text { Potato } \\
\text { yield } \\
\left(\mathrm{t} \mathrm{fed}^{-1}\right)\end{array} \\
15.71\end{array}$} & \multirow{2}{*}{$\begin{array}{l}\text { Org- } \\
\text { Cost }\end{array}$} & \multirow{2}{*}{$\begin{array}{c}\begin{array}{c}\text { Bio- } \\
\text { Cost }\end{array} \\
0\end{array}$} & \multirow{2}{*}{$\begin{array}{c}\begin{array}{c}\text { K- } \\
\text { foliar } \\
\text { Cost }\end{array} \\
0\end{array}$} & \multirow{2}{*}{$\begin{array}{c}\begin{array}{c}\text { K- } \\
\text { applied } \\
\text { Cost }\end{array} \\
1120\end{array}$} & \multirow{2}{*}{$\begin{array}{c}\text { Lab- } \\
\text { ors } \\
\text { Cost }\end{array}$} & \multirow{2}{*}{$\begin{array}{c}\begin{array}{c}\text { Cons- } \\
\text { tant } \\
\text { costs }\end{array} \\
10000\end{array}$} & \multirow{2}{*}{$\begin{array}{c}\text { TC } \\
(\mathrm{L} . \mathrm{E})\end{array}$} & $\begin{array}{c}\text { GR } \\
\text { (L.E) }\end{array}$ & \multirow{2}{*}{$\begin{array}{c}\begin{array}{c}\text { NR } \\
\text { (L.E) }\end{array} \\
10745\end{array}$} & \multirow{2}{*}{$\frac{\mathrm{IF}}{\mathrm{I}}$} \\
\hline \multirow{4}{*}{$\operatorname{rg}_{1}$} & $\mathrm{~K} 1$ & & & & & & & & & 23565 & & \\
\hline & K2 & 15.69 & 1600 & 0 & 320 & 560 & 100 & 10000 & 12580 & 23540 & 10960 & 1.87 \\
\hline & K3 & 15.24 & 1600 & 0 & 320 & 168 & 0 & 10000 & 12088 & 22865 & 10777 & 1.89 \\
\hline & $\mathrm{K} 4$ & 14.86 & 1600 & 0 & 320 & 84 & 0 & 10000 & 12004 & 22285 & 10281 & 1.86 \\
\hline \multirow{4}{*}{$\begin{array}{c}\mathrm{Org}_{1} \\
+ \\
\text { Bio }\end{array}$} & $\mathrm{K} 1$ & 15.80 & 1600 & 30 & 0 & 1120 & 100 & 10000 & 12850 & 23705 & 10855 & 1.84 \\
\hline & $\mathrm{K} 2$ & 15.89 & 1600 & 30 & 320 & 560 & 100 & 10000 & 12610 & 23835 & 11225 & 1.89 \\
\hline & K3 & 15.58 & 1600 & 30 & 320 & 168 & 0 & 10000 & 12118 & 23365 & 47 & 1.93 \\
\hline & $\mathrm{K} 4$ & 15.22 & 1600 & 30 & 320 & 84 & 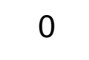 & 10000 & 12034 & 22 & 91 & 1.90 \\
\hline \multirow{4}{*}{$y_{2}$} & $\mathrm{~K} 1$ & 16.40 & 3200 & 0 & 0 & 1120 & 100 & 10000 & 14420 & 24605 & & 1.71 \\
\hline & $\mathrm{K} 2$ & 16 & 3200 & 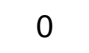 & 320 & 560 & 100 & & & & & 1.73 \\
\hline & $\mathrm{K} 3$ & 16.16 & 3200 & 0 & 320 & 168 & 0 & 10000 & 13688 & 24240 & & 1.77 \\
\hline & $\mathrm{K} 4$ & 15.76 & 320 & 0 & 320 & 84 & 0 & 10000 & 13604 & 23635 & & 1.74 \\
\hline \multirow{4}{*}{$\begin{array}{c}\mathrm{Org}_{2} \\
+ \\
\text { Bio }\end{array}$} & $\mathrm{K} 1$ & 16.68 & 3200 & 30 & 0 & 1120 & 100 & 10000 & 14450 & 25025 & & 1.73 \\
\hline & $\mathrm{K} 2$ & 16.70 & 3200 & 30 & 320 & 560 & 100 & 10000 & 14210 & 25045 & & 1.76 \\
\hline & K3 & 16.32 & 3200 & 30 & 320 & 168 & 0 & 10000 & 13718 & 24480 & 10762 & 1.78 \\
\hline & $\mathrm{K} 4$ & & 3200 & 30 & 320 & 84 & 0 & 000 & 13634 & 23875 & 10241 & 1.75 \\
\hline \multirow{2}{*}{\multicolumn{2}{|c|}{ ean }} & \multicolumn{6}{|c|}{ Mean of Org \pm Bio treaments } & \multicolumn{5}{|c|}{ Mean of K-treatments } \\
\hline & & $\operatorname{Org}_{1}$ & \multicolumn{2}{|c|}{$\mathrm{Org}_{1}+\mathrm{Bio}$} & $\mathrm{Org}_{2}$ & \multicolumn{2}{|c|}{$\mathrm{Org}_{2}+\mathrm{Bio}$} & K1 & \multicolumn{2}{|c|}{ K2 } & No & K4 \\
\hline \multicolumn{2}{|c|}{ NR } & 10691 & \multicolumn{2}{|c|}{11030} & 10296 & \multicolumn{2}{|c|}{10603} & 10590 & \multicolumn{2}{|c|}{10859} & 0835 & 10336 \\
\hline \multicolumn{2}{|c|}{ IF } & 1.86 & \multicolumn{2}{|c|}{1.89} & 1.74 & \multicolumn{2}{|c|}{1.76} & 1.78 & \multicolumn{2}{|c|}{1.81} & 1.84 & 1.81 \\
\hline
\end{tabular}

$\mathrm{Org}_{1}=10 \mathrm{~m}^{3}$ compost fed ${ }^{-1} ; \mathrm{Org}_{2}=20 \mathrm{~m}^{3}$ compost fed ${ }^{-1}$; Bio = inoculation by K-release bacteria;

$\mathrm{K} 1=96 \mathrm{~kg} \mathrm{~K}_{2} \mathrm{O} \mathrm{fed}{ }^{-1} ; \quad \mathrm{K} 2=48 \mathrm{~kg} \mathrm{~K}_{2} \mathrm{O} \mathrm{fed}+1 \% \mathrm{~K}_{2} \mathrm{O}$ foliar; $\mathrm{K} 3=48 \mathrm{~kg} \mathrm{~K}_{2} \mathrm{O}$ fed $^{-1}$ as feldspar $+1 \% \mathrm{~K}_{2} \mathrm{O}$ foliar; $\mathrm{K} 4=24 \mathrm{~kg} \mathrm{~K}_{2} \mathrm{O}$ fed $^{-1}$ as feldspar $+1 \% \mathrm{~K}_{2} \mathrm{O}$ foliar. 


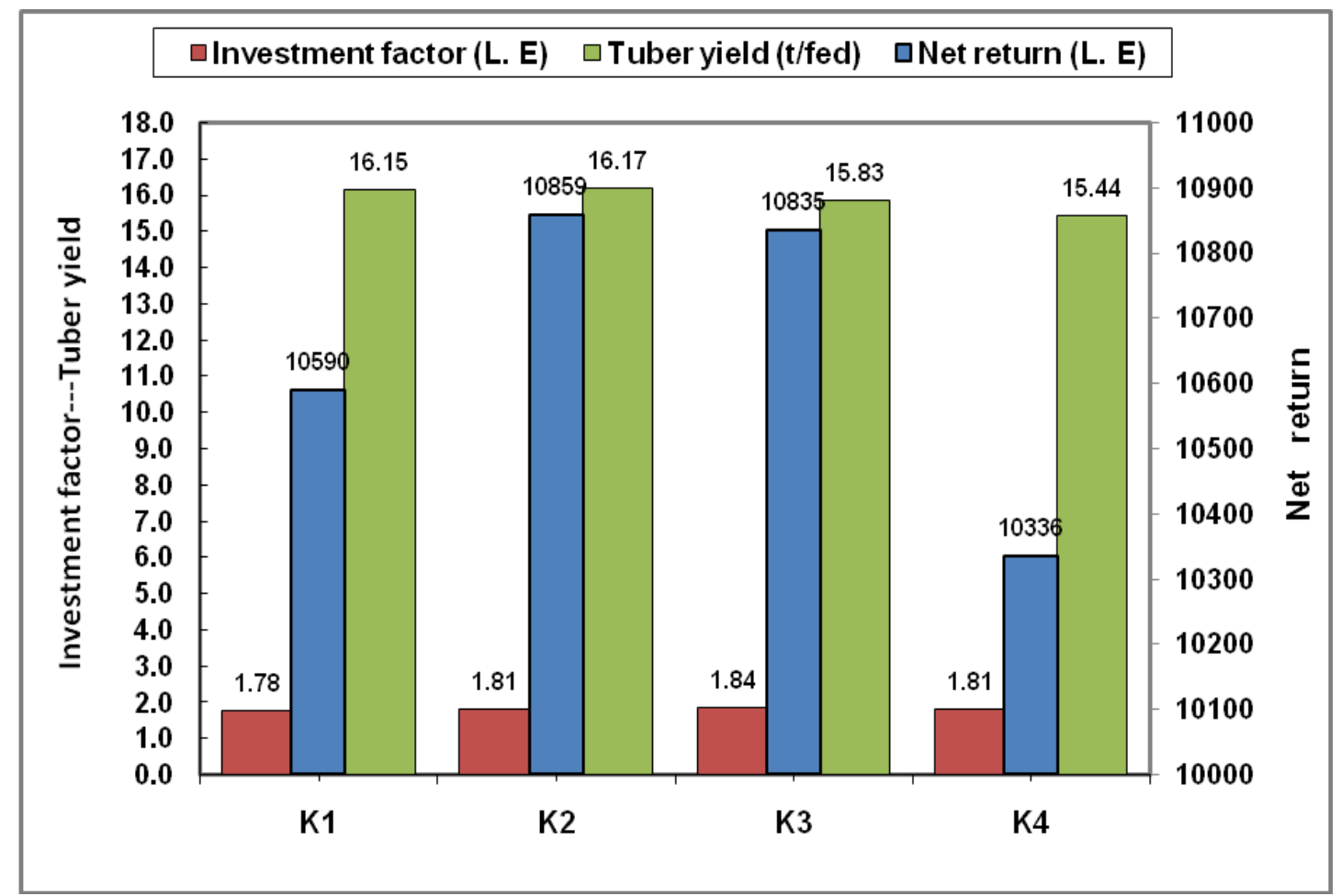

Fig. 1: Influence of K-treatments on tuber yield, net return and investment factor.

As for the effect of organic fertilization data in Table 6 and Fig. 2 reveal that NR and IF values were affected positively by addition of compost levels with or without inoculation with K-release bacteria. As treatments order for NR and IF, they were $\operatorname{Org}_{1}+$ Bio $>\operatorname{Org}_{1}>\operatorname{Org}_{2}+$ Bio $>\operatorname{Org}_{2}$, while for total tubers yield, it was $\mathrm{Org}_{2}+\mathrm{Bio}>\mathrm{Org}_{2}$ $>\operatorname{Org}_{1}+$ Bio $>\operatorname{Org}_{1}$. The highest value of NR and IF was 11030 L.E and 1.89 with application of compost level $10 \mathrm{~m}^{3} \quad(6.5 \mathrm{t}$ $\mathrm{fed}^{-1}$ ) with inoculation by $\mathrm{K}$-release bacteria $\left(\operatorname{Org}_{1}+\mathrm{Bio}\right)$.

Regarding the interactions effect (as shown in Fig. 3), it is clear that the effect of interaction among compost levels with or without inoculation by K-release bacteria and K-treatments on NR and IF was positive, where their values were higher under interaction $\operatorname{Org}_{1}{ }^{*} \mathrm{~K}$ than $\operatorname{Org}_{2}{ }^{*} \mathrm{~K}$, and under interaction $\operatorname{Org}_{1}+\mathrm{Bio}^{*} \mathrm{~K}$ than $\mathrm{Org}_{2}+\mathrm{Bio}{ }^{*} \mathrm{~K}$. The superiority was for interaction of $\mathrm{Org}_{1}+\mathrm{Bio}^{*} \mathrm{~K}$-treatments. The highest values of NR was 11225 and 11247 L.E fed ${ }^{-1}$ with interactions $\operatorname{Org}_{1}+\mathrm{Bio}^{*} \mathrm{~K} 2$ and $\mathrm{Org}_{1}+\mathrm{Bio}^{*} \mathrm{~K} 3$ with IF 1.89 and 1.93 (the highest IF), respectively. Generally, all treatments fulfilled reasonable profitability where IF values were more than 1 , so it could be considered that the superiority was for interaction of $\mathrm{Org}_{1}+\mathrm{Bio}$ with K2 or K3 treatment. These results are accordance with those obtained by El-Sirafy et al., (2008).

Finally from the previous results, it can be noticed that application of $50 \%$ of recommended $\mathrm{K}\left(48 \mathrm{~kg} \mathrm{~K}_{2} \mathrm{O}\right.$ fed $\left.^{-1}\right)$ as SOP or as feldspar with foliar spray of $1 \% \mathrm{~K}_{2} \mathrm{O}$ (K2 and K3) was superior on the most of plant growth parameters, total yield and its components, parameters of tuber quality, NPK-uptake and economic evaluation (NR and IF), as well as compost levels with inoculation with K-release bacteria comparing with traditional K-fertilization (K1: $96 \mathrm{~kg} \mathrm{~K}_{2} \mathrm{O}$ fed $\left.^{-1}\right)$. These may be attributed to 
that K-treatments $\mathrm{K} 2(50 \%$ of Rd-K as SOP+ $1 \% \mathrm{~K}_{2} \mathrm{O}$ foliar) and $\mathrm{K} 3(50 \%$ of $\mathrm{Rd}-\mathrm{K}$ as feldspar+ $1 \% \mathrm{~K}_{2} \mathrm{O}$ foliar) were more efficient on supplying plants at the period of growth until harvest with the highest K-utilization efficiency and with the lowest losses of Kapplied through leaching (El-Sirafy et al., 2008, Singh and Lal, 2012 and Labib et al., 2012). Application of K-treatments K2 and $\mathrm{K} 3$ gave the longest period for plants to uptake its requirements' of $\mathrm{K}$ that agree with every stage of plant growth comparing with traditional K-fertilization K1 (addition of Krecommended doses as soil application, which is more likelihood to be lost through leaching with irrigation water). Application of $\mathrm{K}$ as feldspar increase continuous supply of $\mathrm{K}$ in sandy soil without risk of undesired increase in the soil solution concentration or losses due to leaching, and increase sustainability soil fertility of $\mathrm{K}$ (Shehata, et al., 2014). Also, K-treatments $K 2$ and $K 3$ can save about $50 \%$ of $\mathrm{K}$-recommended. In addition to this, the economic return of $\mathrm{K} 2$ and $\mathrm{K} 3$ comparing with $\mathrm{K} 1$ were high, where $\mathrm{K}$-sulfate fertilizer as export fertilizer is high expensive (arrange from 5600-6000 L.E/t) compare with natural sources as feldspar, which needs an activator to release $\mathrm{K}$, that by addition compost and inoculation with bio-fertilizer that contains K-release bacteria "Bacillus circulans". Application of compost and K-release bacteria also affected chemical, physical and biological properties of experimental sandy soil, which reflected on plants growth, tuber yield and its quality and the uptake of NPK (Abo El-Khair et al., 2009, El-Sayed et al., 2014 and Shehata et al., 2014). It is well known that microbes can enhance mineral dissolution rate by products that interact with the mineral surface such as carbonic acid, acetate, citrate and oxalate in addition to growth promoting substances (Welch and Ullman, 1993).

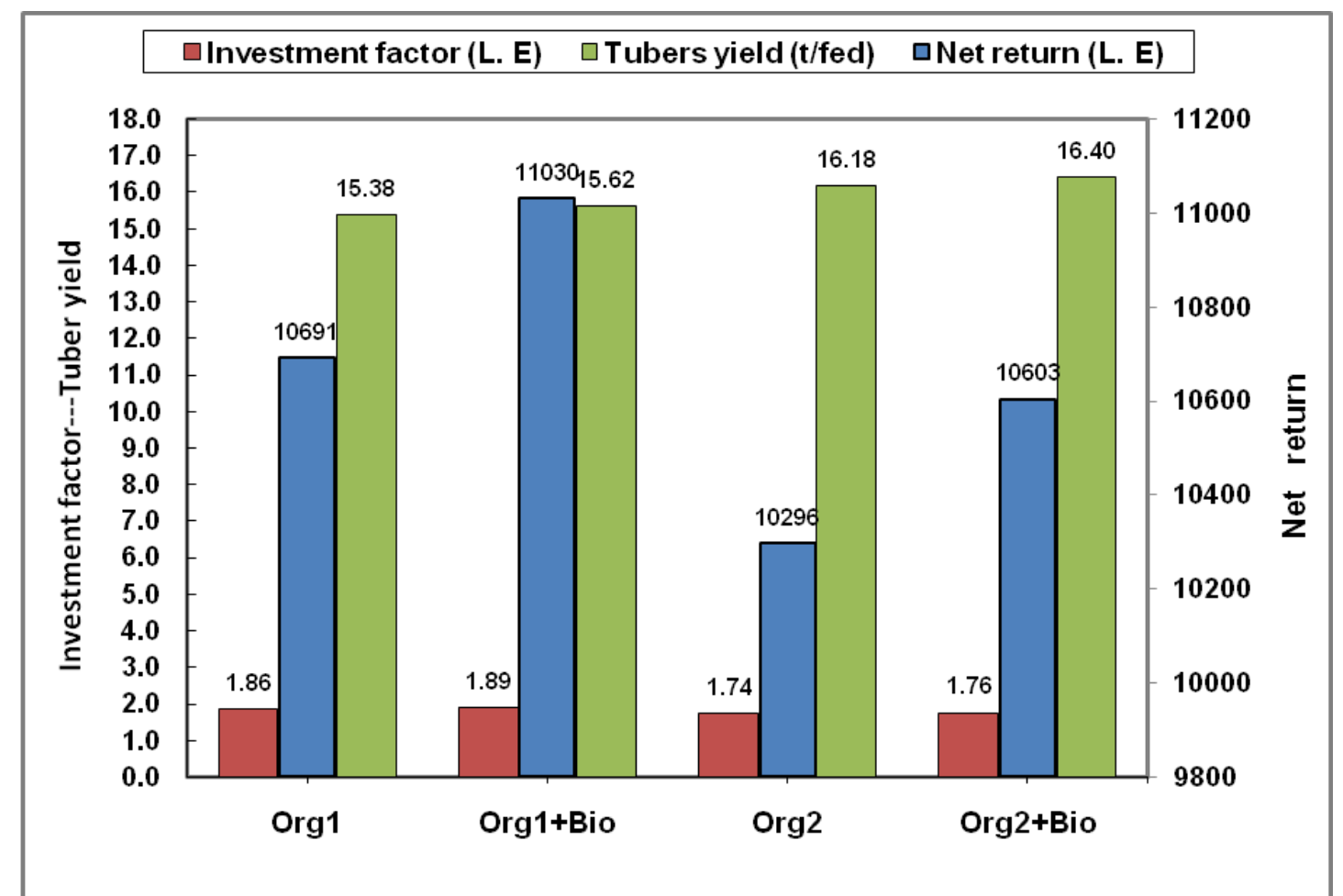

Fig. 2: Influence of compost levels \pm Bio-fertilizer on tuber yield, net return and investment factor. 


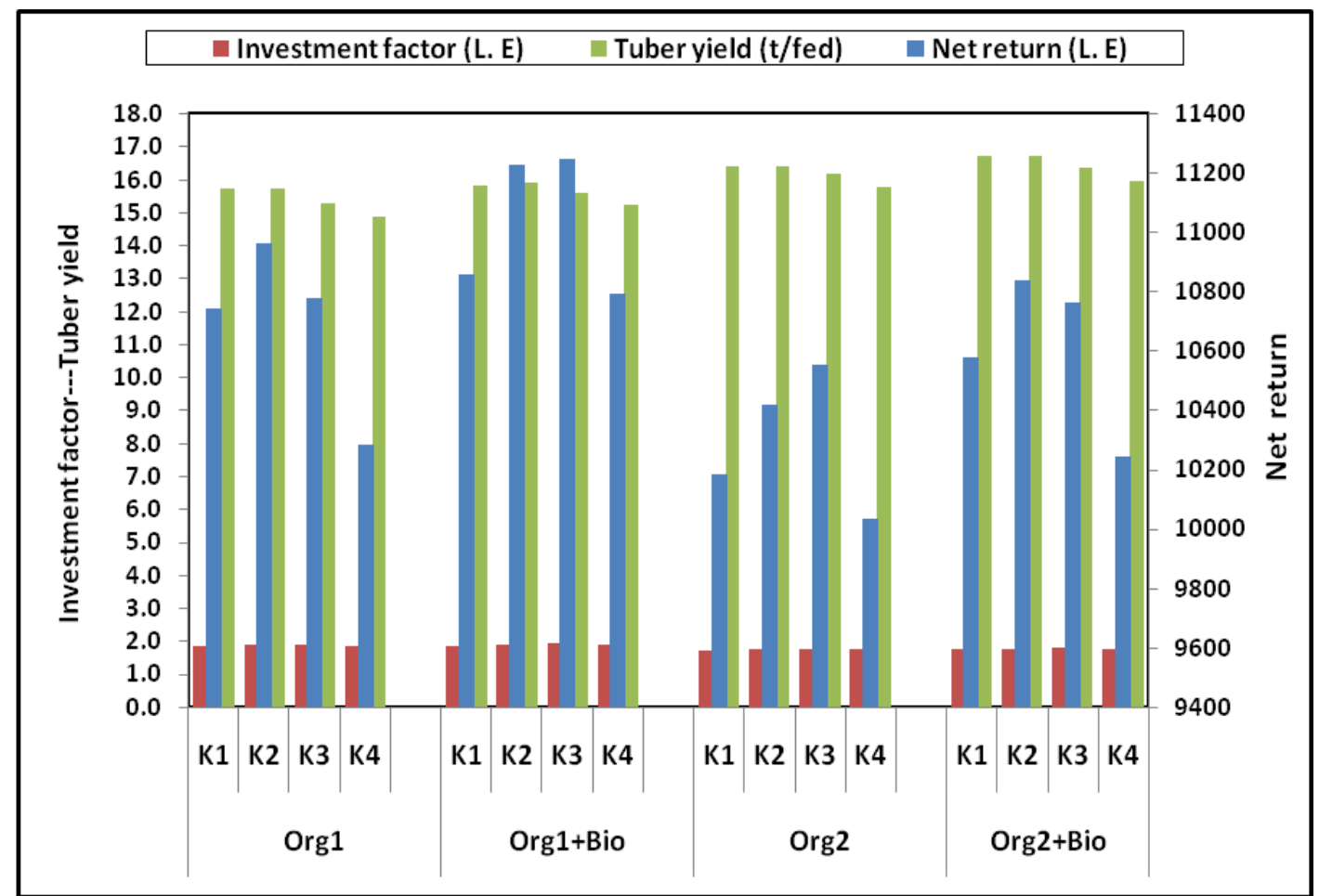

Fig. 3: Influence of interactions on tuber yield, net return and investment factor.

In conclusion; The present study recommends applying $10 \mathrm{~m}^{3}$ compost fed ${ }^{-1}$ with inoculation with bio-fertilizer that contains strains of $\mathrm{K}$-release bacteria (Bacillus circulans) + soil addition of $48 \mathrm{~kg}$ $\mathrm{K}_{2} \mathrm{O}$ fed $^{-1}$ as K-sulfate or feldspar + foliar spray of $1 \% \mathrm{~K}_{2} \mathrm{O}$ (3 times) in addition to the recommended doses of $\mathrm{N}\left(150 \mathrm{~kg} \mathrm{~N}^{-1} \mathrm{fed}^{-1}\right)$ and $\mathrm{P}\left(75 \mathrm{~kg} \mathrm{P}_{2} \mathrm{O}_{5}\right.$ fed $\left.^{-1}\right)$ are necessary to reach optimum yield of potato with high quality and maximum profitability under the same conditions of the studied sandy soil.

\section{REFERENCES}

A. O. A. C. (1990). "Official Methods of Analysis of the Association of Official Analytical Chemists". 15 ${ }^{\text {th }}$ (edition, published by Association of Official Analytical Chemists Arlington, Virginia U.S.A.).

Abo El-Khair, A. W., A. A. Mohamed and A. A. Abd El-Aal (2009). The role of biofertilizers in the availability of potassium for potato crop. J. Agric. Sci. Mansoura Univ., 34(5):4275-4288.

Abou Hussein, S. D., I. El-Oksh, T. ElShorbagy and A. M. Gommaa (2002). Effect of cattle manure, biofertilizers and reducing mineral fertilizer on nutrient content and yield of potato plant. Egypt J. Hort., 29(1):99-115.

Ali, A. A. (2006). Efficiency of potassium fertilizers on potatoes in a newly cultivated sandy soil. Ph. D. Thesis, Fac. Agric. Zagazig Univ.

Al-Moshileh, A. M. and M. A. Errebi (2004). Effect of various potassium sulfate rates on growth, yield and quality of potato grown under sandy soil and arid conditions. IPI regional workshop on Potassium and Fertigation development in West Asia and North Africa, Rabat, Morocco 24-28 November.

Burton, W. G. (1948). "The Potato". Chapman and Hall, London. Pp.319. 
Dkhil, B. B., M. Denden and S. Aboud (2011). Foliar potassium fertilization and its effect on growth, yield and quality of potato grown under loam-sandy soil and semi-arid conditions. Int. J. Agric. Res., 6(7):593-600.

El-Dissoky, R. A. (2008). Studies on the use efficiency of potassium and organic fertilizers on potatoes and its role in improving soil properties. Ph D. Thesis, Fac. Agric. Mansoura Univ., Egypt.

El-Sawy, B. I., E. A. Radawan and N. A. Hassan (2000). Growth and yield of potato as affected by soil and foliar potassium application. J. Agric. Sci. Mansoura Univ., 25(9):5843-5850.

El-Sayed, S. F., H. A. Hassn, M. M. El-Mogy and A. Abdel-Wahab (2014). Growth, yield and nutrient concentration of potato plants grown under organic and conventional fertilizer systems. American Eurasian J. Aric. \& Environ. Sci., 14(7): 636-643.

El-Sirafy, Z. M., Khadra A. Abbady, A. M. ElGhamry and R. A. El-Dissoky (2008). Potato yield quality, quantity and profitability as affected by soil and foliar potassium application. Res. J. Agric. \& Biol. Sci., 4(6): 912-922.

Gomaa-Nadia, M. H. (2007). Response of tuber crops (potato) to potassium fertilization in some soils in Egypt. Ph. D. Thesis, Fac. Agric. Zagazig Univ., Egypt.

Gomez, K. A. and A. A. Gomez (1984). "Statistical Procedures for Agricultural Research". $2^{\text {nd }} \mathrm{Ed}$. John Wiely and Sons, pp. 680.

Hesse, P. R. (1971). "A Text Book of Soil Chemical Analysis". Juan Murry (Publisher) Ltd, London.
Labib, B. F., T. K. Ghabour, I. S. Rahim and M. M. Wahba (2012). Effect of potassium bearing rock on the growth and quality of potato crop (Solanum tuberosum). J. Agric. Biotech. Sustainable Development, 4(1):7-15.

Makaraviciute, A. (2003). Effect of organic and mineral fertilizers on the yield and quality of different potato varieties. Agro. Res., 1(2):197-209.

Munson, R., W. D. Bishop, W. L. Nelson, B. G. Ellis, E. C. Sample, D. A. Hot, M. E. Summer and L. S. Murphy (1985). "Potassium in Agriculture", America. Soci. Agron., Crop Sci. Soc. America, Soil Sci. Soc. America, Madison, Wisconsin, USA.

Ranganna, S. (1977). "Manual of Analysis of Fruits and Vegetable Products". Central Food Technological Research Institute Mysore.

Shehata, S. A., M. A. El-Helaly and M. A. EL-Said (2014). Using natural alternative fertilizers for potato production under sandy soil conditions in Egypt. J. Plant Production, Mansoura Univ., 5(10): 17451757.

Singh, S. K. and S. S. Lal (2012). Effect of potassium nutrition on potato yield, quality and nutrient use efficiency under varied levels of nitrogen application. Potato J. 39(2):155-165.

Smith, N. R. (1975). "Specific Gravity, Potato Processing". The AVI Publishing Comp. Inc., 43-66.

Welch, S. A. and W. J. Ullman (1993). The effect of organic acid on plagioclase dissolution rates and stoichiometry. Geochim. Cosmochim. Acta. 57: 27252736. 


\title{
تأثير التسميد البوتاسي والكمبوست والتلقيح الحيوي علي تحسين إنتاجية وجودة وربحية محصول البطاطس النامي في الأرض الرملية
}

\author{
رمضان عوض الاسوقي ، داليا عدروز سيد ، آمال حسن الجبالي \\ معهذ بحوث الأراضي والمياه والبيئة - مركز البحوث الزراعبة - الجيزة - مصر
}

الملخص العربى إنبى

أصبحت إدارة المغذيات من الأهمية بمكان للحصول على المحصول الأمثل ذو الربحية العظمي، لذا أجريت تجربتان

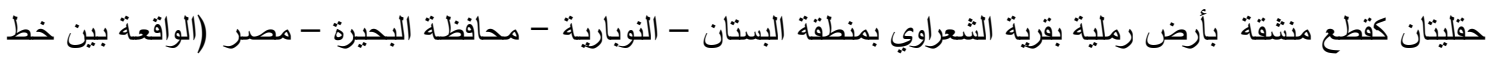

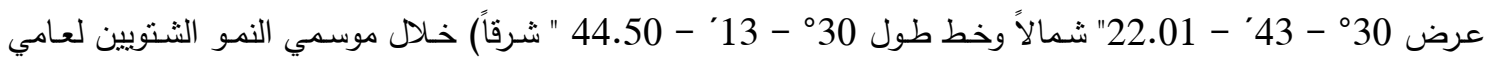
2014 و 2015علي محصول البطاطس- صنف اسبونتا وذلك لتقييم تأثير التسميد العضوي عند معدلين 10 و 20 م3 3

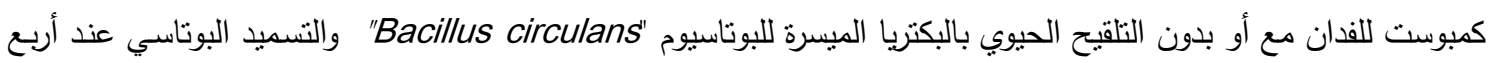

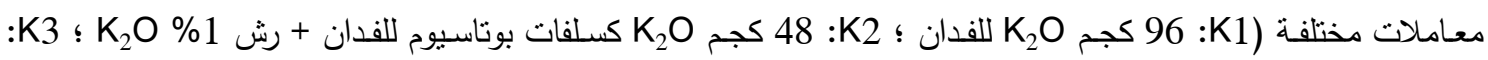

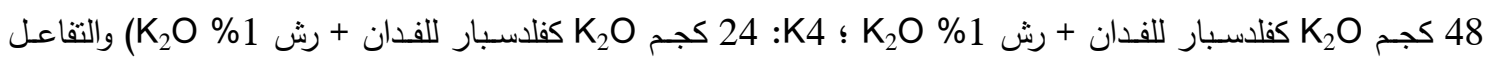
بينهما علي محصول البطاطس ومكوناته وجودنه والمثتص من النتروجين والفوسفور والبوتاسيوم بواسطة محصول الدرنات والعائد الاقتصادي لكل معاملة.

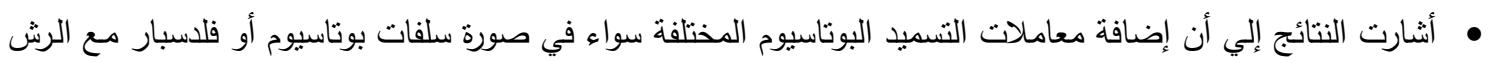

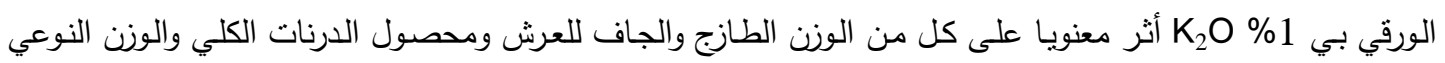

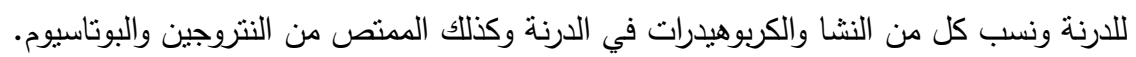

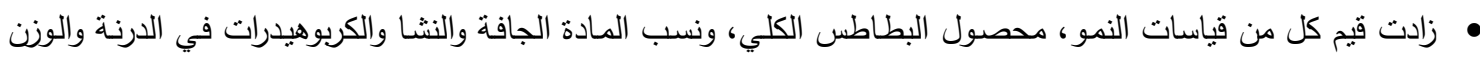

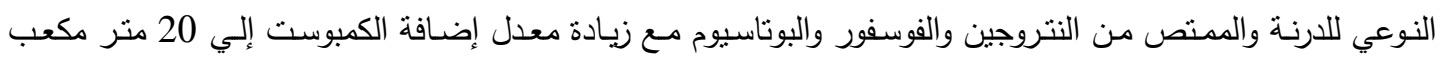
للفدان و التلقيح بالبكتريا الميسرة للبوتاسيوم. • • مقق التفاعل بين مسنوي الكمبوست 20 منر مكعب للفدان + البكتريا الميسرة للبوتاسيوم والتسميد البوتاسي عند

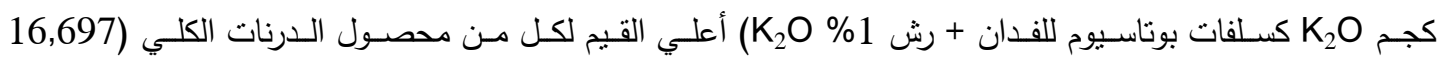

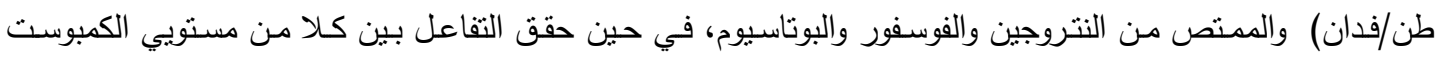

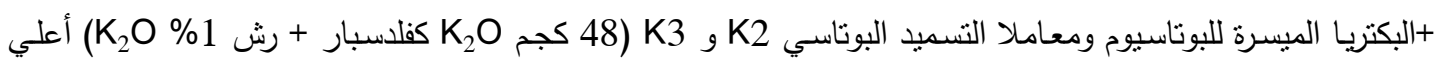
القيم لقياسات الجودة.

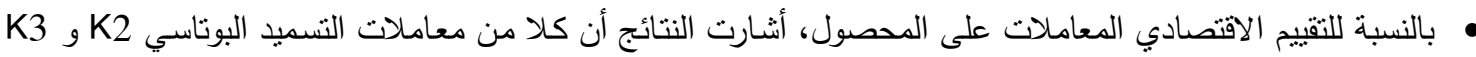
كانتا الأكثر تفوقا بالنسبة للعائد الاقتصادي ومعامل الربحية، هذا وقد حقق التفاعل بين مستوى الكمبوست 10 متر

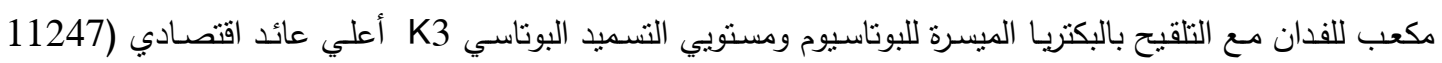
جنية مصري) وأعلي معامل ربحي (1,93).

البريد الالكترونى

E-mail:mujareg@gmail.com
موقع المجلة

Mujareg.blogspot.com 
Potassium fertilization, compost and bio-fertilizer for improving................... 